\title{
Evaluation the Effect of Natural Compounds: Vitamin C, Green Tea, and their Combination on Progression of Mg-63 Osteosarcoma Cell Line Cells. (An In Vitro Study)
}

\author{
Hiam Rifaat Hussien Mohammed ${ }^{1 \star}$, Amr Helmy Moustafa El Bolok ${ }^{2}$, Sherif Farouk Elgayar ${ }^{2}$, Maii Ibrahim Ali Sholqamy ${ }^{2}$ \\ ${ }^{1}$ Department of Oral and Maxillofacial, Pathology Department, Faculty of Dentistry, Minia University, Sohag, Egypt; ${ }^{2}$ Department \\ of Oral and Maxillofacial Pathology, Faculty of Dentistry, Minia University, Minya, Egypt
}

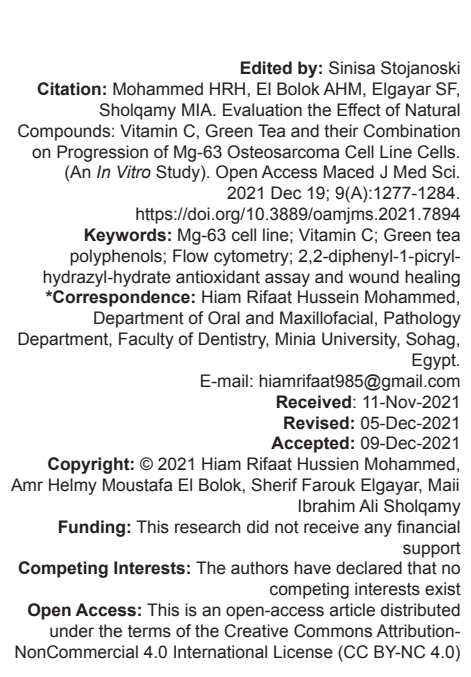

\section{Introduction}

Cancer is considered one of the most common causes of death all over the world according to the recorded global statistics [1], [2]. Osteosarcoma (OS) is a malignant bone tumor of unknown etiology; it has many different histological subtypes that reflect presence of pleomorphic malignant cells which considered the source of osteoid [3]. Recurrence of cancer is based mainly on migration and metastasis of cancer cells. One third of cases of OS develop recurrency, mostly osteolytic bone metastases [4]. There are many different common treatment options of cancer: Surgery, radiation, and chemotherapy [5]. To avoid the adverse effects of these methods, recent studies have been preferred to use natural products and herbal plant extracts that have anticancer properties [6]. Vitamin C is naturally occurred in many different types of food and it also known as ascorbic acid, previously, many different studies assured that
Vitamin $C$ has anticancer effect on cancer cells resulting in cell death of tumor and also it possesses antioxidant capacity [7], [8]. Green tea polyphenols (GTPs) are used in the treatment of cancers as GTPs consist of $80-90 \%$ catechins [9], [10]. Green tea catechins (GTCs) have anticancer properties in many cancer cells as stomach, small intestine, lung, prostate, and breast because they can regulate deoxyribonucleic acid (DNA) methylation, histone modification, cell cycle regulation, apoptosis, invasion, and angiogenesis [11], [12]. GTPs consists of four main polyphenolic flavonoids constituents (epicatechin, epigallocatechin, epicatechin-3gallate, and epigallocatechin-3-gallate (EGCG). [13] Interaction therapy between drugs is used in cancer prevention and treatment. In interaction therapy, the combination may be synergistic, additive, antagonistic, or potentiation interaction of green tea extract and Vitamin $C$ is additive type in which antioxidant property of tea is improved [14]. In our study, we compare the role of natural materials: Vitamin $\mathrm{C}$, green tea, and their combination on Mg-63 cells by studying the effect of 
these natural drugs on cell migration, free radicals, and induction of cell death.

\section{Material and Methods}

\section{SRB cytotoxicity assay}

It is sulforhodamine $B$ (SRB) colorimetric assay for cytotoxicity screening, used for cell density determination, based on the measurement of cellular protein content. It is one of the most important methods for in vitro cytotoxicity.

Mg-63 OS cell line was obtained from Nawah Scientific Inc, (Mokatam, Cairo, Egypt). Cells were maintained in DMEM media supplemented with $100 \mathrm{mg} /$ $\mathrm{mL}$ of streptomycin, 100 units $/ \mathrm{mL}$ of penicillin, $10 \%$ of heat-inactivated fetal bovine serum in humidified, and $5 \%(\mathrm{v} / \mathrm{v}) \mathrm{CO}_{2}$ atmosphere at $37^{\circ}$ [15], [16].

\section{Antioxidant test}

Initial screening step, solution of the provided samples was prepared in concentrations of 1000 and $100 \mu \mathrm{g} / \mathrm{mL}$ in dimethyle sulfoxide to identify a range within which the inhibitory concentration $50 \quad\left(\mathrm{IC}_{50}\right)$ lies. For $\mathrm{IC}_{50}$ determination of free radicals in $\mathrm{Mg}-63$ control cells and treated cells, extracts that exceeded $50 \%$ inhibition in any of the initial screening step concentrations were serially diluted to provide five concentrations. For trolox standard preparation, a stock solution of $100 \mu \mathrm{M}$ concentration of trolox was prepared in methanol from which seven concentrations were prepared including 50,40,30, 20, 15, 10, and $5 \mu \mathrm{M}$. DPPH assay was carried out according to the method of Boly et al., 2016. (1) Briefly; $100 \mu \mathrm{L}$ of freshly prepared DPPH reagent $(0.1 \%$ in methanol) were added to $100 \mu \mathrm{L}$ of the sample in 96 wells plate (n $=6$ ), the reaction was incubated at room temperature for $30 \mathrm{~min}$ in dark. At the end of incubation time, the resulting reduction in DPPH color intensity was measured at $540 \mathrm{~nm}$. Data are represented as means 土. (Figure 1) [17], [18].

\section{Flow cytometric analysis}

\section{Cell cycle analysis}

After treatment Mg-63 with Vitamin C, green tea, and combination for $72 \mathrm{~h}$, cells ( 105 cells) are collected by trypsinization and washed twice with ice-cold (phosphate buffer saline [PBS], pH 7.4). Cells are re-suspended in $2 \mathrm{~mL}$ of $60 \%$ ice-cold ethanol and incubated at $4^{\circ} \mathrm{C}$ for $1 \mathrm{~h}$ for fixation. Fixed cells are washed twice again with PBS ( $\mathrm{pH} 7.4$ ) and re-suspended in $1 \mathrm{~mL}$ of PBS containing $50 \mu \mathrm{g} / \mathrm{mL}$ RNAase A (ribonuclease) and $10 \mu \mathrm{g} / \mathrm{mL}$ propidium iodide (PI). After 20 min of incubation in dark

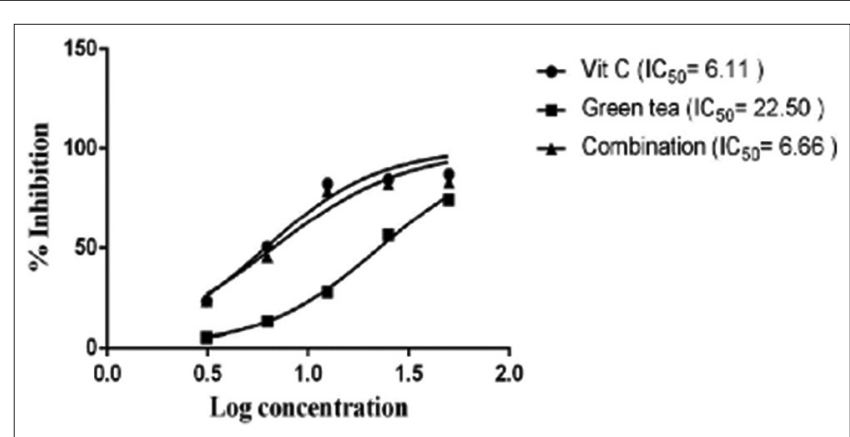

Figure 1: Gram showing IC50 of free radical in Mg-63 treated cells with Vitamin $C$, green tea, and their combinattion

at $37^{\circ} \mathrm{C}$, cells are analyzed for DNA contents using flow cytometry analysis [19], [20], [21], [22], [23].

\section{Apoptosis assay}

Apoptosis and necrosis cell populations are determined using annexin fluorescein isothiocyanate (V-FITC) apoptosis detection kit coupled with two fluorescent channels flow cytometry. After treatment with test compounds for $48 / 72 \mathrm{~h}$, cells (105 cells) are collected by trypsinization and washed twice with icecold PBS ( $\mathrm{pH} 7.4)$. Then, cells are incubated in dark with $0.5 \mathrm{ml}$ of annexin V-FITC/PI solution for $30 \mathrm{~min}$ in dark at room temperature according to the manufacturer protocol. After staining, cells are injected through ACEA Novocyte $^{\mathrm{TM}}$ flow cytometer and analyzed for FITC and $\mathrm{PI}$ fluorescent signals using FL1 and FL2 signal detector, respectively, ( $\lambda$ ex/em $488 / 530 \mathrm{~nm}$ for FITC and $\lambda$ ex/ em535/617 nm for PI). For each sample, 12,000 events are acquired and positive FITC and/or PI cells are quantified by quadrant analysis [19], [20], [21], [22], [23].

\section{Wound healing test}

Cells were plated at density $3 \times 105 /$ well onto a coated 6-well plate for scratch wound assay and cultured overnight. On the next day, scratches were introduced into the confluent monolayer, and the plate was washed thoroughly with PBS. Control wells were replenished with fresh medium while drug wells were treated with fresh media containing drug. Images were taken using an inverted microscope at the indicated time intervals. The plate was incubated at $37^{\circ} \mathrm{C}$ and $5 \% \mathrm{CO}_{2}$ in-between time points' [24], [25], [26], [27], [28], [29]. Wound width and migration rate were calculated.

\section{Results}

\section{SRB cytotoxicity assay}

Data obtained from SRB assay revealed that the half-maximal $\mathrm{IC}_{50}$ of Vitamin $\mathrm{C}$ is $5.5 \mu \mathrm{g} / \mathrm{ml}$, green 


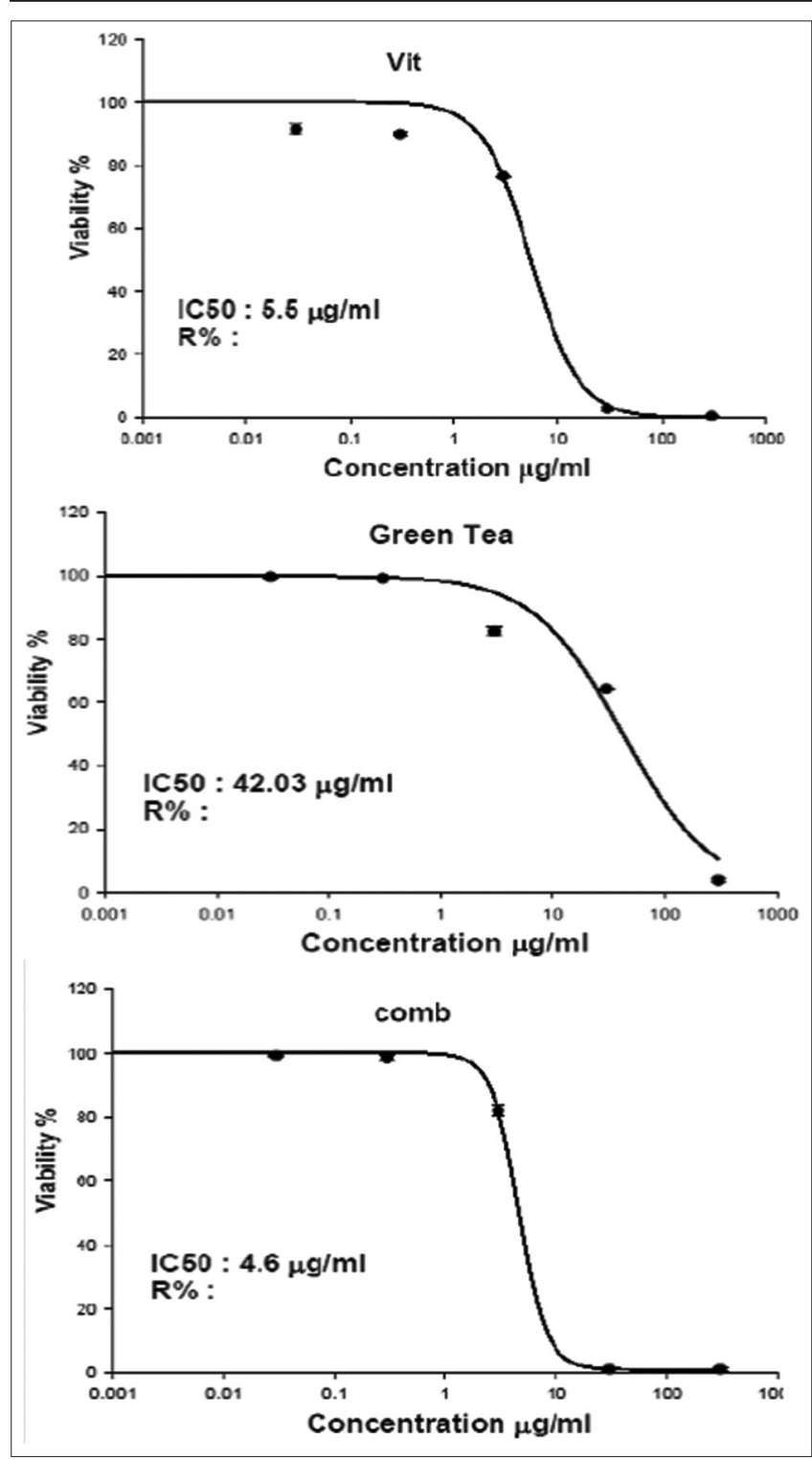

Figure 2: Effect of different concentrations of Vitamin C, green tea, and their combination with $I C_{50}$ on Mg-63 cell line for $72 h$

tea is $42.03 \mu \mathrm{g} / \mathrm{ml}$, and their combination is $4.6 \mu \mathrm{g} / \mathrm{ml}$ on Mg-63 treated cells (Figure 2).

Table 1: IC ${ }_{50}$ of free radicals in Mg-63 treated cells with Vitamin $\mathrm{C}$, green tea, and their combinattion compared to trolox

\begin{tabular}{ll}
\hline Sample & $\mathrm{IC}_{50}($ Mean $\pm \mathrm{SE})$ \\
\hline Vitamin C $(\mu \mathrm{g} / \mathrm{mL})$ & $6.11 \pm 1.04$ \\
Green tea $(\mu \mathrm{g} / \mathrm{mL})$ & $22.50 \pm 1.02$ \\
Combination $(\mu \mathrm{g} / \mathrm{mL})$ & $6.66 \pm 1.07$ \\
Trolox $(\mu \mathrm{g} / \mathrm{mL})$ & $5.61 \pm 0.87$ \\
\hline
\end{tabular}

\section{Antioxidant results}

Table 1 shows $\mathrm{IC}_{50}$ of free radicals in $\mathrm{Mg}-63$ treated cells with Vitamin $\mathrm{C}$, green tea, and their combination compared to trolox. Vitamin $\mathrm{C}$ has the most
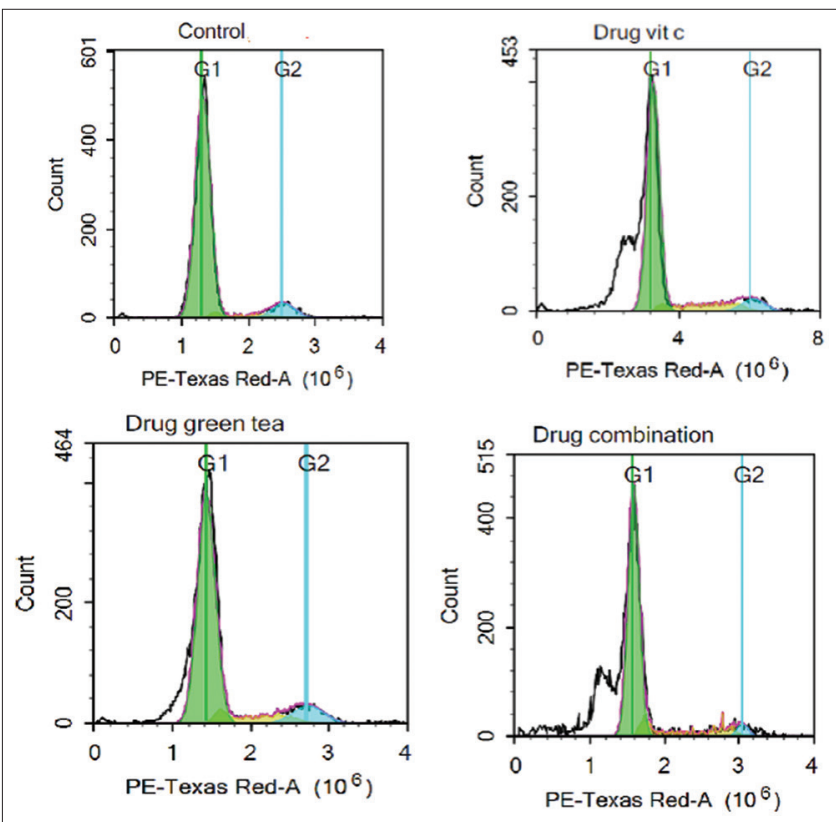

Figure 3: Distribuation of cells in cell cycle phases of control cells, Vitamin c, green tea, and combination treated cell

antioxidant property on Mg-63 treated cells followed by their combination with green tea and the last one is green tea. $\mathrm{IC}_{50}$ of free radicals of Vitamin $\mathrm{C}$ treated cells is $6.11 \mu \mathrm{g} / \mathrm{mL}, 22.50 \mu \mathrm{g} / \mathrm{mL}$ for green tea treated cells, and $6.66 \mu \mathrm{g} / \mathrm{mL}$ for compounds combination treated cells.

\section{Flow cytometry results}

\section{Cell cycle analysis}

The $\mathrm{IC}_{50}$ concentration of Vitamin $\mathrm{C}$, green tea, and compound combination produced pre-G1 apoptosis. As the percentages of cells in pre-G1 are increased when compared to the control cells. There is cell cycle arrest at G2/M phases in green tea treated cells when compared to control cells. On the other hand, in Vitamin $\mathrm{C}$ and drug combination treated cells, the percentages of cells in G2/M phases decreased(Figure 3). when compared to the control cells as shown in Table 2 and Figure 4a-d.

Table 2: Cells distribution in cell cycle phases of control and treated cells of Mg-63 cells

\begin{tabular}{lllll}
\hline & Frequency G1 & Frequency S & Frequency G2 & Sub-G1 \\
\hline Control & 84.19 & 5.20 & 8.80 & 0.84 \\
Vitamin C & 60.07 & 9.98 & 6.15 & 23.46 \\
Green Tea & 74.02 & 10.35 & 10.16 & 4.64 \\
Drug combination & 58.08 & 11.38 & 2.80 & 26.87 \\
\hline
\end{tabular}

\section{Assessment of apoptosis}

The $I_{50}$ concentration of Vitamin C, green tea, and drug combination increased cell death of 
Mg-63 cells when compared to control untreated Mg-63 cells. The highest fraction of control cells is living cells (in the lower right quadrant) with only few necrotic and apoptotic cells. The living cells of treated Mg-63 cells are decreased with an increasing in apoptotic and necrotic cells (apoptotic cells in the upper and lower left quadrant and necrotic cells in the upper right quadrant). Figure 5 and Table 3 showing that the total percentage of apoptotic and necrotic cells is highest in Vitamin $\mathrm{C}$, followed by drug combination and finally green tea treated $\mathrm{Mg}-63$ cells.

Table 3: Effect of Mg-63 treated cells with Vitamin C, green tea, and their combination on apoptosis and necrosis

\begin{tabular}{|c|c|c|c|c|c|}
\hline Sample data & $\begin{array}{l}\text { \% Normal } \\
\text { intact cells } \\
\text { Q2-3 }\end{array}$ & $\begin{array}{l}\text { \% Early } \\
\text { Apoptosis } \\
\text { Q2-4 }\end{array}$ & $\begin{array}{l}\text { \% Late } \\
\text { Apoptosis } \\
\text { Q2-2 }\end{array}$ & $\begin{array}{l}\% \\
\text { Necrosis } \\
\text { Q2-1 }\end{array}$ & $\begin{array}{l}\text { \% Total } \\
\text { Apoptosis and } \\
\text { Necrosis }\end{array}$ \\
\hline Control cells & $98.67 \%$ & 0.19 & 0.48 & 0.66 & 1.33 \\
\hline $\begin{array}{l}\text { Vitamin C } \\
\text { treated cells }\end{array}$ & 95.35 & 0.23 & 1.55 & 2.87 & 4.65 \\
\hline $\begin{array}{l}\text { Green tea } \\
\text { treated cells }\end{array}$ & 98.33 & 0.33 & 0.91 & 0.44 & 1.68 \\
\hline $\begin{array}{l}\text { Compounds } \\
\text { combination } \\
\text { treated cells }\end{array}$ & $95.45 \%$ & 0.40 & 1.63 & 2.52 & 4.55 \\
\hline
\end{tabular}

\section{Wound healing assay}

The wound width decreases as cell migration is induced. The Vitamin C treated cells showed the widest wound when compared to green tea and compounds combination treated cells (Figure 4 and Table 4). Meanwhile, the migration rate of Vitamin C treated cells was least when compared to other groups (Figure 6).

\section{Discussion}

In the present research, we establish that there is a cytotoxic effect of natural compounds: Vitamin C, green tea, and their combination on Mg-63 OS cell line, but in different levels. The most cytotoxic effect was occurred in Vitamin C treated cells, followed by drug combination and finally green tea treated cells. This different effect based on the structure of each compound and their properties. The cytotoxic effects were in a concentration dependent manner as the mean viability percentage of Vitamin $\mathrm{C}$, green tea, and their combination treated cells in relation to control cells were increased with decrease concentrations of the three drugs (Figure 2). These results are in agreement with (Ngo et al., 2019) [30] who said that

Table 4: Wound width of treated samples after $72 \mathrm{~h}$

\begin{tabular}{lll}
\hline Data samples & $72 \mathrm{~h}$ & \\
\cline { 2 - 3 } & Mean $(\mathrm{mm})$ & Standard deviation \\
\hline Vitamin C treated cells & 0.673 & 0.126 \\
Green tea treated cells & 0 & 0 \\
Compounds combination treated cells & 0.09 & 0.123 \\
\hline
\end{tabular}

the high concentrations of Vitamin $\mathrm{C}$ have antitumor, anti-proliferative effects, and produced apoptosis on different OS cell lines as Mg-63 and G292 cell lines. In addition, (Valenti et al., 2014) [4] reported that depending on past researches Vitamin $C$ in the high concentrations suppressed growth of $\mathrm{Mg}-63$ cells results in apoptosis but in the low concentrations resulted in differentiation of the same cell lines. (Ni et al., 2018) [31] who studied the cytotoxicity effect of EGCG in colon adenocarcinoma (COIO205) cells were exposed to $\operatorname{EGCG}(5,10,20,40$, and $80 \mu \mathrm{g} / \mathrm{mL})$ for $24 \mathrm{~h}$. The results showed that cells number dropped when treated with $40 \mu \mathrm{g} / \mathrm{mL}$ EGCG also demonstrated that EGCG induced genetic abnormalities in COLO205 cells and apoptosis, and inhibition of mitosis. These results suggested that EGCG affected cancer cells genetically and cytologically.

Regarding to antioxidant DPPH test, trolox is a soluble form of Vitamin $\mathrm{E}$ and is used as a standard antioxidant against which the antioxidant capacity of compounds is compared. The data revealed that the Vitamin $\mathrm{C}$, green tea, and combination of both compounds have antioxidant properties on Mg-63 cells. These results are in agreement with (Cimmino et al., 2018) [32] studies of who reported that Vitamin $\mathrm{C}$ is considered as a natural antioxidant agent and (Intra and Kuo, 2007) [33]; who stated that the polyphenols in tea are responsible for its antioxidant properties mainly EGCG. Our results showed that the combination between green tea and Vitamin $\mathrm{C}$ is more potent as antioxidant than green tea on treated cells. This result is supported by a study of (Majchrzak et al. 2004) [14] who reported that the antioxidant properties of tea are induced when is combined with Vitamin C.

Our flow cytometry results revealed that Vitamin C, green tea, and combination affected cell cycle and apoptosis of Mg-63 cells. The combination treated cells showed higher ability to arrest cell cycle at G0/G1 phase when compared to Vitamin $\mathrm{C}$ and green tea treated cells. This is supported by apoptotic assessment which revealed that there are $2.03 \%$ of cells.

(Zhou et al., 2020) [34] reported that the Vitamin C can cause G0/G1 cell cycle arrest and mitochondrial caspase-dependent apoptosis in oral squamous cell carcinoma cell line. GTCs especially EGCG has ability to arrest cell cycle at G0/G1 phase of prostate cell line with apoptosis induction (Gupta et al., 2000) [35] and (Umeda et al., 2008) [36] revealed that green tea has can arrest cell cycle at G2/M phase, which is in agreement with our result, as the only green tea treated cells showed accumulation of cells at G2/M phase when compared to control cells. (Gupta et al. 2003) [37] demonstrated that EGCG causes cell cycle arrest resulting in apoptosis, this potential effect of EGCG through using it alone or in combination with other.

Wound healing assays revealed that the migration rate of MG-63 cells is influenced by Vitamin 


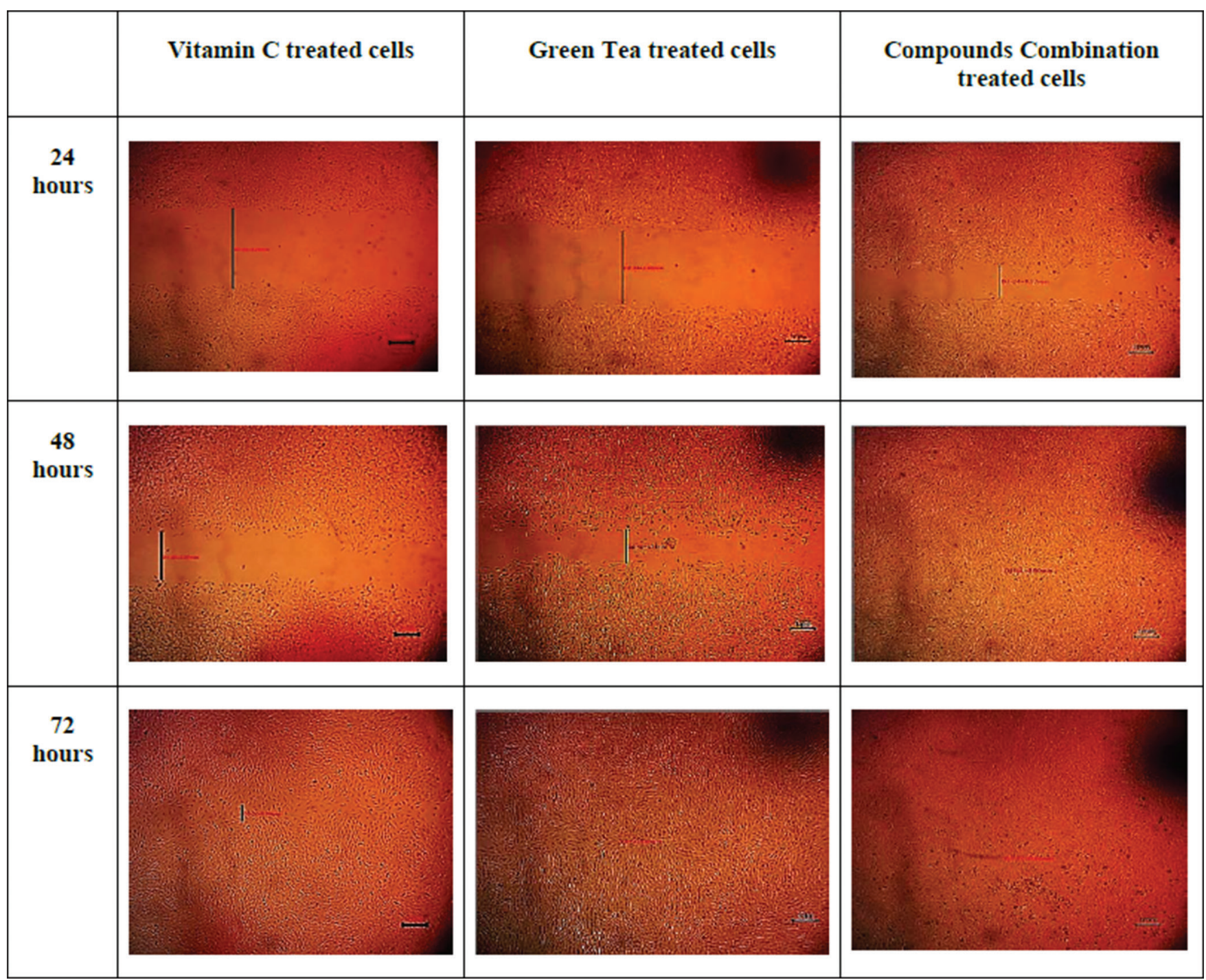

Figure 4: Effect of Mg-63 treated cells with VitaminC, green tea, and their combination on wound healing after $24 \mathrm{~h}, 48 \mathrm{~h}$, and $72 \mathrm{~h}$
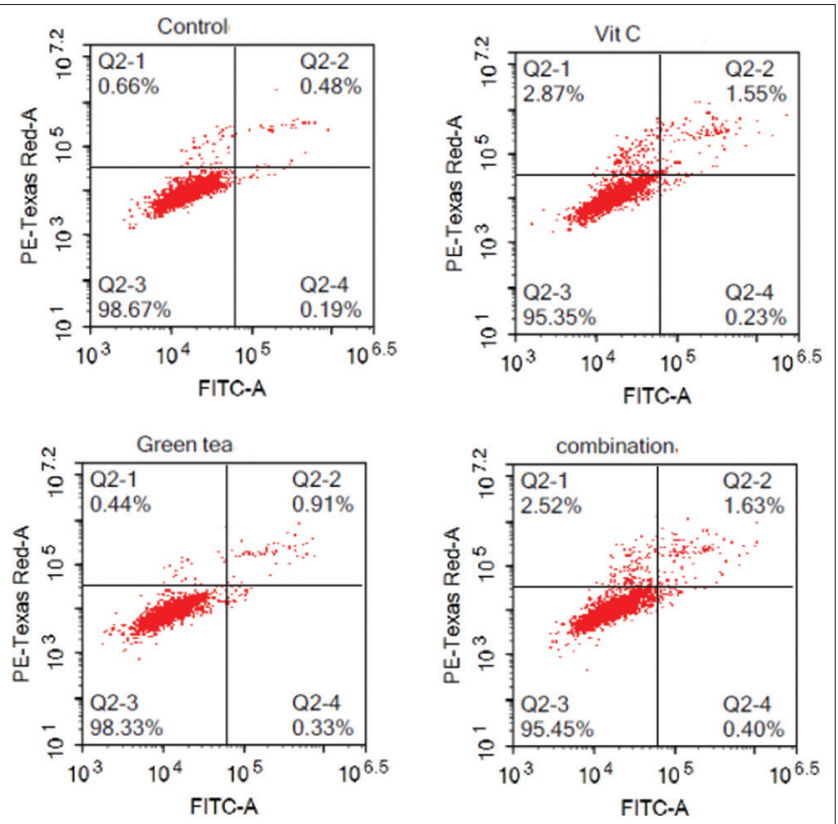

Figure 5: Effect of Mg-63 treated cells with VitaminC, green tea, and their combination of apoptosis and necrosis
C, green tea, and combination of both compounds. After $72 \mathrm{~h}$, the wound width was widest in Vitamin C treated cells when compared to green tea and compounds combination treated cells. Meanwhile, the Vitamin C treated cells showed that least migratory property followed by combination treated cells and finally green tea treated cells when compared to control untreated cells. Our results are in agreement with (Zhou et al., 2020) [35] who reported that the Vitamin $C$ inhibits the migration of oral squamous cell carcinoma CAL27 cells, this is may be due to ability of Vitamin C to inhibit osteopontin (Valenti et al., 2014) [4]. EGCG of GTCs inhibits migration and metastasis of lung metastasis of melanoma cells, this is explained as EGCG downregulate epithelium-mechanism transition and matrix metalloproteinase (Liu et al. 2017) [34], [38].

Further studies are needed to establish the effect of Vitamin C, green tea, and their combination on cancer cells and order to confirm the effect of these natural compounds on progression of tumor cells. 


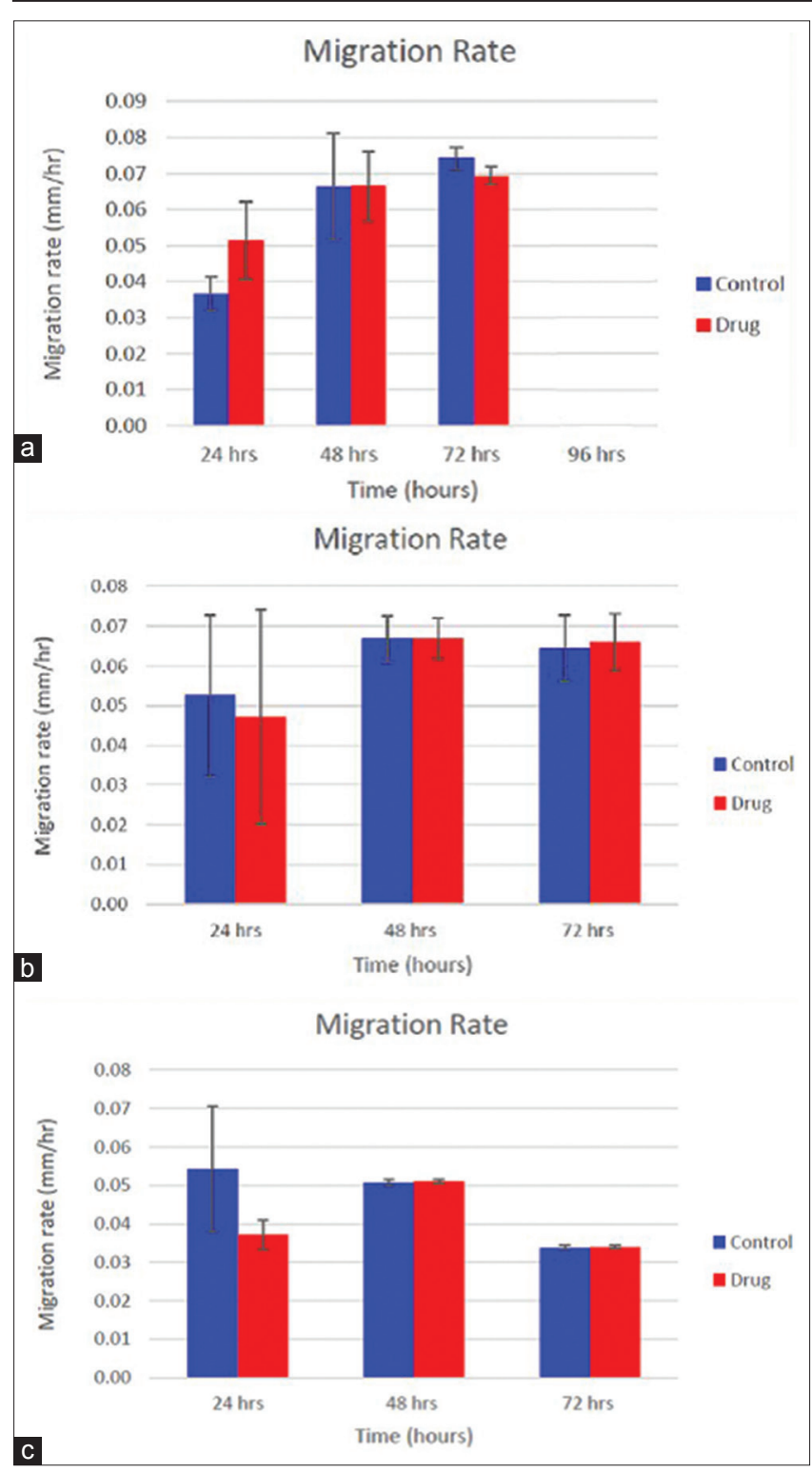

Figure 6: Effect of Mg-63 treated cells with Vitamin C (a), green tea (b), and their combination (c) on migration rate after $24 h, 48 h$, and $72 h$

\section{Conclusions}

Vitamin C, green tea, and their combination have a cytotoxic effect on Mg-63 cell line. They also arrest cell cycle with induction of apoptosis and necrosis. These drugs possess antioxidant capacity. Vitamin C, green tea, and their combination decrease metastasis of MG63 cells as they have property to inhibit cell migration. The combination between Vitamin $\mathrm{C}$ and green tea has highest effect on cell cycle arrest and apoptosis. While, Vitamin $\mathrm{C}$ has more antioxidant property than green tea and their combination on MG-63 cells. Furthermore, Vitamin C inhibits migration of MG-63 cells more than green tea and their combination.

\section{References}

1. Ferlay J, Ervik M, Lam F, Colombet M, Mery L, Piñeros M, et al., editors. Global Cancer Observatory: Cancer Today. Lyon, France: International Agency for Research on Cancer; 2020. Available from: https://www.gco.iarc.fr/today [Last accessed on 2020 Nov 25].

2. Ferlay J, Ervik M, Lam F, Colombet M, Mery L, Piñeros M, et al. Global Cancer Observatory: Cancer Today. Lyon: International Agency for Research on Cancer; 2020. Available from: https:// www.gco.iarc.fr/today [Last accessed on 2020 Nov 25].

3. Lindsey BA, Markel JE, Kleinerman ES. Osteosarcoma overview. Rheumatol Ther. 2017;4(1):25-43. https://doi. org/10.1007/s40744-016-0050-2

\section{PMid:27933467}

4. Valenti MT, Zanatta M, Donatelli L, Viviano G, Cavallini C, Scupoli MT, et al. Ascorbic acid induces either differentiation or apoptosis in MG-63 osteosarcoma lineage. Anticancer Res. 2014;34(4):1617-27. PMid:24692690

5. Zhang J, Gao F, Yang AK, Chen WK, Chen SW, Li H, et al Epidemiologic characteristics of oral cancer: Single-center analysis of 4097 patients from the Sun Yat-Sen University Cancer Center. Chin J Cancer. 2016;35(1):24. https://doi. org/10.1186/s40880-016-0078-2

PMid:26940066

6. Sivaraj R, Rahman PK, Rajiv P, Narendhran S, Venckatesh R. Biosynthesis and characterization of Acalypha indica mediated copper oxide nanoparticles and evaluation of its antimicrobial and anticancer activity. Spectrochim Acta A Mol Biomol Spectrosc. 2014;129:255-8. https://doi.org/10.1016/j.saa.2014.03.027

PMid:24747845

7. Kasinski AL, Kelnar K, Stahlhut C, Orellana E, Zhao J, Shimer $\mathrm{E}$, et al. A combinatorial microRNA therapeutics approach to suppressing non-small cell lung cancer. Oncogene. 2015;34(27):3547-55. https://doi.org/10.1038/onc.2014.282 PMid:25174400

8. Harris HR, Orsini N, Wolk A. Vitamin C and survival among women with breast cancer: A meta-analysis. Eur J Cancer 2014;50(7):1223-31. https://doi.org/10.1016/j.ejca.2014.02.013 PMid:24613622

9. Bedrood Z, Rameshrad M and Hosseinzadeh H. Toxicological effects of Camellia sinensis (green tea): A review. Phytother Res. 2018;32(7):1163-80. https://doi.org/10.1002/ptr.6063 PMid:29575316

10. Fujiki H, Sueoka E, Watanabe T, Suganuma M. Synergistic enhancement of anticancer effects on numerous human cancer cell lines treated with the combination of EGCG, other green tea catechins, and anticancer compounds. J Cancer Res Clin Oncol. 2015;141(9):1511-22. https://doi.org/10.1007/ s00432-014-1899-5

PMid:25544670

11. Fujiki H, Watanabe $T$, Sueoka E, Rawangkan A, Suganuma M. Cancer prevention with green tea and its principal constituent, EGCG: From early investigations to current focus on human cancer stem cells. Mol Cells. 2018;41(2):73-82. https://doi. org/10.14348/molcells.2018.2227 PMid:29429153

12. Toden S, Okugawa $\mathrm{Y}$, Jascur $\mathrm{T}$, Wodarz $\mathrm{D}$, Komarova NL, Buhrmann $\mathrm{C}$, et al. Curcumin mediates chemosensitization to 5-fluorouracil through miRNA-induced suppression of 
epithelial-to-mesenchymal transition in chemoresistant colorectal cancer. Carcinogenesis. 2015;36(3):355-67. https:// doi.org/10.1093/carcin/bgv006

PMid:25653233

13. Sauter ER. Cancer prevention and treatment using combination therapy with natural compounds. Expert Rev Clin Pharmacol. 2020;13(3):265-85. https://doi.org/10.1080/17512433.2020.173 8218

PMid:32154753

14. Majchrzak D, Mitter S, Elmadfa I. The effect of ascorbic acid on total antioxidant activity of black and green teas. Food Chem. 2004;88(3):447-51. https://doi.org/10.1016/j. foodchem.2004.01.058

15. Skehan P, Storeng R, Scudiero D, Monks A, McMahon J, Vistica $D$, et al. New colorimetric cytotoxicity assay for anticancerdrug screening. J Natl Cancer Inst. 1990;82(13):1107-12. https:// doi.org/10.1093/jnci/82.13.1107

PMid:2359136

16. Allam RM, Al-Abd AM, Khedr A, Sharaf OA, Nofal SM, Khalifa $A E$, et al. Fingolimod interrupts the cross talk between estrogen metabolism and sphingolipid metabolism within prostate cancer cells. Toxicol Lett. 2018;291:77-85. https://doi. org/10.1016/j.toxlet.2018.04.008

PMid:29654831

17. Boly R, Lamkami T, Lompo M, Dubois J, Guissou I. DPPH free radical scavenging activity of two extracts from Agelanthus dodoneifolius (Loranthaceae) leaves. Int J Toxicol Pharm Res. 2016;8(1):29-34.

18. Chen Z, Bertin R, Froldi G. EC50 estimation of antioxidant activity in DPPH assay using several statistical programs. Food Chem. 2013;138(1):414-20. https://doi.org/10.1016/j. foodchem.2012.11.001 PMid:23265506

19. Fekry MI, Ezzat SM, Salama MM, Alshehri OY, Al-Abd AM. Bioactive glycoalkaloides isolated from Solanum melongena fruit peels with potential anticancer properties against hepatocellular carcinoma cells. Sci Rep. 2019;9(1):1746. https:// doi.org/10.1038/s41598-018-36089-6

PMid:30741973

20. Bashmail HA, Alamoudi AA, Noorwali A, Hegazy GA, AJabnoor $\mathrm{G}$, Choudhry $\mathrm{H}$, et al. Thymoquinone synergizes gemcitabine anti-breast cancer activity via modulating its apoptotic and autophagic activities. Sci Rep. 2018;8(1):11674. https://doi.org/10.1038/s41598-018-30046-z

PMid:30076320

21. Baghdadi MA, Al-Abbasi FA, El-Halawany AM, Aseeri AH, Al-Abd AM. Anticancer profiling for coumarins and related O-naphthoquinones from Mansonia gagei against solid tumor cells in vitro. Molecules. 2018;23(5):1020. https://doi. org/10.3390/molecules23051020

PMid:29701706

22. Alaufi OM, NoorwaliA, Zahran F,Al-AbdAM,Al-Attas S. Cytotoxicity of thymoquinone alone or in combination with cisplatin (CDDP) against oral squamous cell carcinoma in vitro. Sci Rep. 2017;7(1):13131. https://doi.org/10.1038/s41598-017-13357-5

PMid:29030590

23. Mohamed GA, Al-Abd AM, El-Halawany AM, Abdallah HM, Ibrahim SR. New xanthones and cytotoxic constituents from Garcinia mangostana fruit hulls against human hepatocellular, breast, and colorectal cancer cell lines. J Ethnopharmacol. 2017;198:302-12. https://doi. org/10.1016/j.jep.2017.01.030

PMid:28108382
24. Main KA, Mikelis CM, Doçi CL. In vitro wound healing assays to investigate epidermal migration. In: Epidermal Cells. New York: Humana; 2019. p. 147-54.

25. Martinotti S, Ranzato E. Scratch Wound Healing Assay. In: Turksen K, editor. Epidermal Cells. Methods in Molecular Biology. Vol. 2109. New York: Humana; 2019.

26. Lie MR, van der Giessen J, Fuhler GM, de Lima A, Peppelenbosch MP, van der Ent C, et al. Low dose Naltrexone for induction of remission in inflammatory bowel disease patients. J Transl Med. 2018;16(1):55. https://doi.org/10.1186/ s12967-018-1427-5

PMid:29523156

27. Rueden CT, Schindelin J, Hiner MC, DeZonia BE, Walter AE, Arena ET, et al. ImageJ2: ImageJ for the next generation of scientific image data. BMC Bioinformatics. 2017;18(1):526. https://doi.org/10.1186/s12859-017-1934-z

PMid:29187165

28. Schindelin J, Arganda-Carreras I, Frise E, Kaynig V, Longair M, Pietzsch T, et al. Fiji: An open-source platform for biologicalimage analysis. Nat Methods. 2012;9(7):676-82. https://doi. org/10.1038/nmeth.2019

PMid:22743772

29. Rodriguez LG, Wu X, Guan JL. Wound-healing assay. In: Cell Migration. New Jersey, United States: Humana Press; 2005. p. 23-9.

30. Ngo B, van Riper JM, Cantley LC, Yun J. Targeting cancer vulnerabilities with high-dose Vitamin C. Nat Rev Cancer. 2019;19(5):271-82. https://doi.org/10.1038/s41568-019-0135-7 PMid:30967651

31. Ni J, Guo X, Wang H, Zhou T, Wang X. Differences in the effects of EGCG on chromosomal stability and cell growth between normal and colon cancer cells. Molecules. 2018;23(4):788. https://doi.org/10.3390/molecules23040788

PMid:29596305

32. Cimmino L, Neel BG, Aifantis I. Vitamin C in stem cel reprogramming and cancer. Trends Cell Biol. 2018;28(9):698708. https://doi.org/10.1016/j.tcb.2018.04.001

PMid:29724526

33. Intra J, Kuo SM. Physiological levels of tea catechins increase cellular lipid antioxidant activity of Vitamin C and Vitamin $E$ in human intestinal caco-2 cells. Chem Biol Interact. 2007;169(2):91-9. https://doi.org/10.1016/j. cbi.2007.05.007

PMid: 17603031

34. Zhou J, Chen C, Chen X, Fei Y, Jiang L, Wang G. Vitamin C promotes apoptosis and cell cycle arrest in oral squamous cell carcinoma. Front Oncol. 2020;10:976. https://doi.org/10.3389/ fonc. 2020.00976

PMid: 32587830

35. Gupta S, Ahmad N, Nieminen AL, Mukhtar H. Growth inhibition, cell-cycle dysregulation, and induction of apoptosis by green tea constituent (-)-epigallocatechin-3-gallate in androgensensitive and androgen-insensitive human prostate carcinoma cells. Toxicol Appl Pharmacol. 2000;164(1):82-90. https://doi. org/10.1006/taap.1999.8885

PMid: 10739747

36. Umeda D, Yano S, Yamada K, Tachibana H. Involvement of $67-\mathrm{kDa}$ laminin receptor-mediated myosin phosphatase activation in antiproliferative effect of epigallocatechin-3-Ogallate at a physiological concentration on Caco-2 colon cancer cells. Biochem Biophys Res Commun. 2008;371(1):172-6. https://doi.org/10.1016/j.bbrc.2008.04.041

PMid:18423375 
37. Gupta S, Hussain T, Mukhtar H. Molecular pathway for (-)-epigallocatechin-3-gallate-induced cell cycle arrest and apoptosis of human prostate carcinoma cells. Arch Biochem Biophys. 2003;410(1):177-85. https://doi.org/10.1016/ s0003-9861(02)00668-9

PMid:12559991
38. Liu L, Ju Y, Wang J, Zhou R. Epigallocatechin-3gallate promotes apoptosis and reversal of multidrug resistance in esophageal cancer cells. Pathol Res Pract. 2017;213(10):1242-50. https://doi.org/10.1016/j. prp.2017.09.006

PMid:28964574 